\title{
Effects of processing and ice storage on lipid classes and fatty acids of ray muscle (Raja clavata)
}

M José Fernández-Reiriz, Laura Pastoriza, Gabriel Sampedro \& Juan J. R. Herrera lnstituto de Investigaciones Marinas (C.S.I.C.), Eduardo Cabello, 6.- 36208 Vigo, Spain

The effect of ice storage on the lipid material (total lipids, lipid classes and fatty acids) of whole and minced ray muscle has been studied.

Neither processing nor ice storage for seven days significantly changed $(p>0.05)$ the total lipid content. The main fatty acids were: $22: 6 n-3,16: 0,18: 1 n-9,18: 0,20: 5 n-3$, 20:4n-6, and 22:5n-3 in both whole and minced ray muscle. The contents of these fatty acids increased significantly $(\mathrm{p}<0.001)$ during seven days of storage in the ice state, except those of 20:4n-6 and 20:5n-3, which decreased significantly $(p<0.01)$. The contents of the different fatty acids (saturated, monoenes, and polyunsaturated) increased significantly $(\mathrm{p}<0.001)$ owing to both mincing and storage in ice.

Phospholipids, sterol esters + waxes, triacylglycerides, free fatty acids, and sterols were studied. Phospholipids were the main lipid group in ray muscle. No significant differences $(\mathrm{p}<0.01)$ were found as a consequence of mincing and ice storage in the contents of phospholipids and sterols. However, significant differences $(p<0.01)$ appeared in the free-fatty-acid content after seven days of storage in ice, but mincing did not affect this.

\section{INTRODUCTION}

Ray is an abundant fishing resource that has undergone growing exploitation in recent years and become a suitable raw material for technological use in the transformation industry and in the elaboration of new and original fish-food products (Pastoriza \& Sampedro, 1991). However, few studies have been undertaken on the biochemical changes taking place on rayfish muscle.

Important changes occur in the fish lipid fraction during processing and produce a consequent loss of quality in the food product (Fernández-Reiriz et al., 1992). The study 
of the processes that constitute the lipid modification phenomenon is complex.

Saturated fatty acids, monoenes, and polyunsaturated fatty acids are found in fatty fish, and, among the last-mentioned ones, those of the n-3 HUFA series (highly unsaturated fatty acids, i.e. 20:5n-3, 22:5n-3, and 22:6n-3) are outstanding. This composition gives a high vulnerability, which is at the origin of the oxidation processes. They can thus be classified as the most unstable edible lipids.

Ray (Raja clavata) is ice-stored on board prior to being commercialized as fresh fish. Minced fish muscle has around the interest of the industry in preparing formulated frozen products, such as dried formulated products, battered and breaded frozen products, dried fish-flesh flakes, or powders as additives for other products, fish sticks, surimi, etc.

Changes in lipids take place as a result of hydrolysis and oxidation reactions, which affect the quality of the fish-food product. Thus, the study of the changes that occur in fatty acids and in the different classes of lipids-phospholipids, triacylglycerides, free fatty acids, sterols and sterol esters plus waxes-during the storage of rayfish muscle in the ice state has been the objective of the present research. The effect of mincing the fresh ray as well as the ice stored ray was also studied.

\section{MATERIALS AND METHODS}

The ray (Raja clavata) were caught off the Galician coast in April 1990 and kept in ice for less than 24 hours before being processed. The wings were cut off the fish trunk and skinned manually. The samples were packed in polyethylene bags, stored in containers with ice, and kept in a chill room at $2+2^{\circ} \mathrm{C}$ for seven days. Ten fish samples were analysed.

Samples were minced at the beginning of the experiment (day O) and after seven days in the ice state. Mincing was carried out in a mincer (Mobba 3CV) by using a disc with 8-mm-diameter holes.

Lipids were extracted by the method of Bligh \& Dyer (1959) as modified by FernándezReiriz et al. (1989). Two analyses were made on each sample. 
Total lipids, fatty acids, and classes of lipids were determined according to FernándezReiriz et al. (1992). Nonetheless, some modifications were made in the quantitative analysis of lipid classes. Thus, cholesteryl palmitate and palmityl, arachiric acid, cholesterin, oleic acid, and cod liver oil (CLO, Sigma) were used as standards for sterol esters + waxes, sterols, free fatty acids, and triacylglycerols, respectively. Each determination was performed in duplicate.

Peroxide value was calculated according to Wheeler (1932, as cited by Mehlenbacher, 1970). Ash content was determined by ashing at $550^{\circ} \mathrm{C}$ for 24 hours.

A Tukey test was applied for statistical analyses (Sokal \& Rohlf, 1969).

\section{RESULTS AND DISCUSSION}

The total lipid and ash contents (as percentage dry weight) of whole and minced ray muscle are shown in Table 1. Similar percentages were obtained irrespective of processing and ice storage, i.e. around 3.5\%, and 3.7\% for lipids and ashes, respectively. No significant differences were found $(p>0.05)$.

Fatty-acid composition

The fatty-acid composition of rayfish muscle is shown in Table 2 (mg fatty acid/g dry weight).

At the beginning of the experiment (day 0 ), the main fatty acids were 22:6n-3, 16:0, 18:1n-9, 18:0, 20:5n-3, 20:4n-6, and 22:5n-3 in both whole and minced ray muscle. The contents of these fatty acids increased significantly $(p<0.01)$ in whole muscle stored in ice, with the exception of 20:5n-3 and 20:4n-6, which decreased significantly $(p<0.01)$. Mincing (day 0) gave rise to the same tendency as storage of whole fish in ice for seven days, but a non-significant decrease occurred in the content of 20:4n-6 in comparison with whole fresh fish at day 0 . If whole fish kept in the ice state for seven days was minced, an increase in the content of the main fatty acids occurred. However, statistical 
analysis showed significant differences $(\mathrm{p}<0.01)$ only for $22: 6 \mathrm{n}-3,16: 0,20: 5 \mathrm{n}-3$, and $22: 5 n-3$.

The contents of the different fatty acids increased significantly $(p<0.001)$ as a result of both ice, storage and mincing. The polyunsaturated fatty acids were $52.26 \%$, monoene fatty acids, $16-18 \%$, and saturated fatty acids, $31.55 \%$ of the fatty-acid content in whole ray muscle at the beginning of the experiment (day 0 ). The contents of saturated and polyunsaturated fatty acids decreased significantly $(\mathrm{p}<0.01)$ i.e. $30.98 \%$ and $51-90 \%$, respectively, whereas that of monoene fatty acids increased significantly (17-12\%) after seven days in ice $(\mathrm{p}<0-01)$.

Changes take place in fish lipids owing to handling and technological factors, such as preservation treatments, time and conditions of storage, etc. (Wood \& Hintz, 1971; Bilinski et al., 1983; Nair \& Gopakumar, 1985; Suzuki et al., 1985; De Koning et al., 1987; Barassi et al., 1987; Fazal \& Srikar, 1987; Fernández-Reiriz et al., 1992). These changes cause colorations in fish muscle that play an important role in the appearance, presentation, and acceptability of the food product (Young \& Whittle, 1985). They also give rise to the appearance of off-flavours and a unpleasant smell as a consequence of a loss in the unsaturation degree of the polyunsaturated fatty acids (PUFA fraction) (Shenouda, 1980; Srikar et al., 1989). Subsequently, a loss in nutritive value and quality results in the final product.

Dietary studies have emphasised that n-3 PUFA fatty acids help to reduce the risk of cardiovascular illnesses, hence it is important to consume fish products rich in these fatty acids. Ray has a high n-3 PUFA content (especially of docosahexaenoic acid), higher than that of any other marine or fresh-water fish. Pastoriza \& Sampedro (1992) also observed a high polyunsaturated-fatty-acid content in ray (Raja radiata).

Fish lipids are highly susceptible to oxidative rancidity, particularly during cold storage, since they generally contain a high proportion of unsaturated fatty acids with four, five, or six double bonds. However, peroxide value did not reveal any important oxidation of the polyunsaturated fatty acids during the storage of ray wings in the ice state.

\section{Lipid classes}


The composition of the different classes of lipids is shown in Table 3.

Phospholipids were the major component of the classes of lipids. Phospholipids and sterols decreased (not significantly: $p>0.05$ ) during the storage in ice. The variations associated with mincing were not significant either $(\mathrm{p}>0.05)$.

A significant increase $(p<0.01)$ in the free-fatty-acid content resulted after seven days in the ice state, but mincing did not give rise to significant differences $(p>0-01)$. An increase in free fatty acids has been reported to occur owing to storage in ice or in the frozen state (Bligh, 1961, in cod; Ingemansson et al., 1992, in trout; Fernández-Reiriz et al., 1992, in ray).

Phospholipids are susceptible to hydrolysis, and the free-fatty-acid content has been found to increase when the phospholipid content decreases. Bosund \& Ganrot (1969) pointed out that $45-75 \%$ of the FFA fraction of herring stored in the frozen state came from the phospholipid fraction and the rest from triacylglycerols. Hardy et al. (1979) suggested that free fatty acids were formed from phospholipids, whereas neutral lipids remained stable in cod kept in the frozen state. Later, De Koning et al. (1987) observed that the formation of free fatty acids was not limited to hydrolysis of phospholipids but also originated from neutral lipids, and Ingemansson et al. (1992) suggested that free fatty acids might result from hydrolysis of triglycerides.

This study appears to indicate that the formation of free fatty acids in ray muscle stored in ice could be used to predict the quality of the fish and as an index of deterioration during ice storage. Barasi et al. (1987) suggested that FFA determination could be used as a valuable alternative to sensory scoring in determining deterioration of fish stored in ice.

\section{ACKNOWLEDGEMENTS}

Thanks are due for the support of the Interministerial Comission of Science and Technology (CICYT) in the Research Project AL1 89-0555. We wish to thank J. L. 
Garrido and Ana Ayala for their technical help in the GLC and TLC analyses, and Ma Cruz Núñez and $\mathrm{M}^{\mathrm{a}}$ Teresa Cascallar for their collaboration.

\section{REFERENCES}

Barassi, C. A., Pécora, R. P., Roldán, H. \& Trucco, R. E. (1987). Total, non-volatile free fatty acids as a freshness index for hake (Merluccius hubbsi) stored in ice. J. Sci. Food Agric., 38, 373-7.

Bilinski, E., Jonas, R. E. E. \& Peters, M. D. (1983). Factors controlling the deterioration of the spiny dogfish Squalus acanthias, during iced storage. J. Food Sci., 48, 808-12.

Bligh, E. G. (1961). Lipid hydrolysis in frozen cod muscle. J. Fish. Res. Board Can., 18, 143-5.

Bligh, E. G. \& Dyer, W. L. (1959). A rapid method of total lipid extraction and purification. Can. J. Biochem. Physiol., 37, 911-17.

Bosund, I. \& Ganrot, B. (1969). Lipid hydrolysis in frozen Baltic herring. J. Food Sci., $34,13-18$.

De Koning, A. J., Milkovitch, S. \& Mol, Th. H. (1987). The origin of free fatty acids formed in frozen cape hake mince (Merluccius capensis, Castelnau) during cold storage at $-18^{\circ}$ C. J. Sci. Food Agric., 39, 79-84.

Fazal, A. A. \& Srikar, L. N. (1987). Changes in flesh lipids of seer fish during frozen storage. J. Food Sci., 24, 303-5.

Fernández-Reiriz, M. J., Pérez-Camacho, A., Ferreiro, M. J., Blanco, J., Planas, M., Campos, M. J. \& Labarta, U. (1989). Biomass production and variation in the biochemical profile (total protein, carbohydrates, RNA, lipids and fatty acids) of seven species of marine microalgae. Aquaculture, 183, 17-37.

Fernández-Reiriz, M. J., Pastoriza, L. \& Sampedro, G. (1992). Lipid changes in muscle tissue of ray (Raja clavata) during processing and frozen storage. J. Agric. Food Chem., 40, 484-8.

Hardy, R., McGill, A. S. \& Gunstone, F. D. (1979). Lipid and auto-oxidative changes in cold stored cod (Gadus morhua). J. Sci. Food Agric., 30, 999-1006.

Ingemansson, T., Kaufmann, P. \& Pettersson, A. (1992). Lipid deterioration in frozen stored muscle tissue of rainbow trout (Oncorhynchus mykiss) in relation to water temperature and carotenoid content. In Quality Assurance in the Fish Industry, ed. H. H. Huss, M. Jakobsen, J. Liston, Elsevier, London, pp. 29-38. 
Mehlenbacher, W. C. (1970). Análisis de grasas y aceites. Ediciones Urmo, Bilbao, Spain.

Nair, P. G. V. \& Gopakumar, K. (1985). Selective release of fatty acids during lipid hydrolysis in frozen-stored milk fish (Chanos chanos). Fish. Technol., 22, 1-4.

Pastoriza, L. \& Sampedro, G. (1991). Quality study in canned products made from ray wings (Raja radiata): Chemical composition and sensorial evaluations. Paper presented at Conference on Quality Assurance in the Fish Industry, Lyngby, Copenhagen, Denmark, abstract p. 48.

Pastoriza, L. \& Sampedro, G. (1992). Chemical composition of the muscle tissue of ray (Raja radiata) from Terranova. Food Chem., 44, 127-9.

Shenouda, S. K. (1980). Theories of protein denaturation during frozen storage of fish flesh. Adv. Food Res., 26, 275-311.

Sokal, R. R. \& Rohlf, F. J. (1969). Biometry. H. Freeman, New York.

Srikar, L. N., Seshadari, H. S. \& Fazal, A. A. (1989). Changes in lipids and proteins of marine catfish (Tachysurus dussumieri) during frozen storage. Int. J. Sci. Technol., $24,653-8$

Suzuki, H., Wada, S., Hayakawa, S. \& Tamura, S. (1985). Effects of oxygen absorber and temperature on $\mathrm{w}-3$ polyunsaturated fatty acids of sardine oil during storage. J. Food Sci., 50, 358-60.

Wood, G. \& Hintz, L. (1971). Lipid changes associated with the degradation of fish tissue. J. Assoc. Off. Anal Chem., 54, 1019-23.

Young, K. W. \& Whittle, K. J. (1985). Colour measurement of fish minces using Hunter L, a, b values. J. Sci. Food Agric., 36, 383-92. 
Table 1. Lipids and ashes ( $\%$ dry weight) in whole and minced ray muscle

\begin{tabular}{lllll}
\hline & \multicolumn{3}{l}{0 days } & \multicolumn{3}{l}{7 days } \\
\cline { 2 - 5 } & Whole & Minced & Whole & Minced \\
\hline Ash & $3.69(0.06)^{\mathrm{a}}$ & $3.64(0.05)^{\mathrm{a}}$ & $3-83(0.07)^{\mathrm{a}}$ & $3.71(0-05)^{\mathrm{a}}$ \\
Lipids & $3.55(0.05)^{\mathrm{a}}$ & $3.87(0.04)^{\mathrm{a}}$ & $3.95(0.03)^{\mathrm{a}}$ & $3.86(0.04)^{\mathrm{a}}$
\end{tabular}

Standard deviations in parentheses, $\mathrm{n}=2$.

The sample was minced when it arrived in the laboratory (day 0) and after the wings had been kept in ice storage for seven days.

Means within the same rows with different superscript letters are significantly different $(\mathrm{p}<0.05)$.

Table 2. Fatty acids and fatty-acid families in whole and minced ray muscle (mg/g dry weight)

\begin{tabular}{|c|c|c|c|c|}
\hline \multirow[b]{2}{*}{ Fatty acid } & \multicolumn{2}{|l|}{0 days } & \multicolumn{2}{|l|}{7 days } \\
\hline & Whole & Minced & Whole & Minced \\
\hline $14: 0$ & $0.084(0.01)^{\mathrm{a}}$ & $0.102(0.02)^{b}$ & $0.072(0.01)^{\mathrm{c}}$ & $0.073(0.01)^{\mathrm{c}}$ \\
\hline $16: 0$ & $1.91(0.02)^{\mathrm{a}}$ & $2.074(0.15)^{\mathrm{b}}$ & $2.32(0.15)^{\mathrm{c}}$ & $2.40(0.12)^{\mathrm{d}}$ \\
\hline $16: 1 \mathrm{n}-7$ & $0.085(0.01)^{\mathrm{a}}$ & $0.080(0.02)^{\mathrm{a}}$ & $0.129(0.01)^{b}$ & $0.130(0.01)^{b}$ \\
\hline $17: 0$ & $0.087(0.01)^{\mathrm{a}}$ & $0.098(0.02)^{\mathrm{a}, \mathrm{b}}$ & $0.104(0.01)^{\mathrm{b}}$ & $0.087(0.01)^{\mathrm{a}}$ \\
\hline $17: 1 n-7$ & $0.079(0.01)^{\mathrm{a}}$ & $0.117(0.01)^{b}$ & $0.102(0.01)^{\mathrm{b}}$ & $0.111(0.01)^{b}$ \\
\hline $18: 0$ & $0.602(0.02)^{\mathrm{a}}$ & $0.712(0.03)^{b}$ & $0.665(0.02)^{\mathrm{c}}$ & $0.700(0.04)^{b, c}$ \\
\hline $18: 1 n-9$ & $0.803(0.03)^{\mathrm{a}}$ & $0.870(0.05)^{\mathrm{b}}$ & $0.988(0.04)^{b}$ & $1.04(0.09)^{\mathrm{b}}$ \\
\hline $18: 1 n-7$ & $0.218(0.04)^{\mathrm{a}}$ & $0.259(0.01)^{\mathrm{b}}$ & $0.281(0.03)^{b}$ & $0.290(0.01)^{\mathrm{b}}$ \\
\hline $18: 2 n-6$ & $0.105(0.01)^{\mathrm{a}}$ & $0.091(0.02)^{\mathrm{a}}$ & $0.105(0.01)^{\mathrm{a}}$ & $0.099(0.01)^{\mathrm{a}}$ \\
\hline $18: 3 n-6$ & $0.058(0.01)$ & $0.000(0.00)$ & $0.000(0.00)$ & $0.000(0.00)$ \\
\hline $20: 1 n-9$ & $0.189(0.02)^{\mathrm{a}}$ & $0.203(0.01)^{\mathrm{b}}$ & $0.248(0.01)^{\mathrm{c}}$ & $0.230(0.03)^{\mathrm{d}}$ \\
\hline $20: 3 n-6$ & $0.091(0.01)^{\mathrm{a}}$ & $0.115(0.01)^{b}$ & $0.123(0.01)^{b}$ & $0.145(0.01)^{\mathrm{c}}$ \\
\hline $20: 4 n-6$ & $0.429(0.03)^{\mathrm{a}}$ & $0.414(0.02)^{\mathrm{a}}$ & $0.376(0.02)^{b}$ & $0.369(0.01)^{\mathrm{b}}$ \\
\hline $20: 5 n-3$ & $0.552(0.02)^{\mathrm{a}}$ & $0.314(0.02)^{b}$ & $0.403(0.03)^{\mathrm{c}}$ & $0.441(0.02)^{\mathrm{d}}$ \\
\hline $22: 5 n-3$ & $0.29(0.02)^{\mathrm{a}}$ & $0.343(0.01)^{\mathrm{b}}$ & $0.370(0.02)^{\mathrm{c}}$ & $0.423(0.02)^{\mathrm{d}}$ \\
\hline $22: 6 n-3$ & $2.92(0.10)^{\mathrm{a}}$ & $3.34(0.18)^{b}$ & $3.92(0.20)^{\mathrm{c}}$ & $4.13(0.18)^{\mathrm{d}}$ \\
\hline Saturated & $2.68(0.03)^{\mathrm{a}}$ & $2.99(0.15)^{b}$ & $3.16(0.15)^{\mathrm{c}}$ & $3.26(0.12)^{d}$ \\
\hline Monoenes & $1.37(0.05)^{\mathrm{a}}$ & $1.53(0.05)^{b}$ & $1.75(0.05)^{\mathrm{c}}$ & $1.80(0.05)^{\mathrm{d}}$ \\
\hline
\end{tabular}




\begin{tabular}{|c|c|c|c|c|}
\hline Polyunsaturated & $4.44(0.11)^{\mathrm{a}}$ & $4.62(0.18)^{b}$ & $5.30(0.20)^{\mathrm{c}}$ & $5.61(0.18)^{\mathrm{d}}$ \\
\hline$\Sigma \mathrm{n}-3$ & $3.76(0.10)^{\mathrm{a}}$ & $4.00(0.10)^{b}$ & $4.69(0.20)^{\mathrm{c}}$ & $5.00(0.18)^{\mathrm{d}}$ \\
\hline$\Sigma \mathrm{n}-6$ & $0.68(0.03)^{\mathrm{a}}$ & $0.620(0.03)^{b}$ & $0.604(0.02)^{b}$ & $0.614(0.02)^{\mathrm{d}}$ \\
\hline$\Sigma \mathrm{n}-7$ & $0.382(0.04)^{\mathrm{a}}$ & $0.456(0.02)^{b}$ & $0.513(0.03)^{\mathrm{c}}$ & $0.531(0.02)^{\mathrm{c}}$ \\
\hline$\Sigma \mathrm{n}-9$ & $0.992(0.03)^{\mathrm{a}}$ & $1.07(0.05)^{\mathrm{b}}$ & $1.24(0.04)^{\mathrm{c}}$ & $1.27(0.09)^{\mathrm{d}}$ \\
\hline n-3 PUFA & $3.76(0.10)^{\mathrm{a}}$ & $4.00(0.10)^{b}$ & $4.69(0.20)^{\mathrm{c}}$ & $5.00(0.18)^{\mathrm{d}}$ \\
\hline$n-3 / n-6$ & $5.50^{\mathrm{a}}$ & $6.45^{\mathrm{b}}$ & $7.77^{\mathrm{c}}$ & $8.14^{\mathrm{d}}$ \\
\hline
\end{tabular}

Standard deviations in parentheses, $\mathrm{n}=2$.

The sample was minced when it arrived in the laboratory (day 0) and after the wings had been kept in ice storage for seven days.

Means within the same rows with different superscript letters are significantly different $(\mathrm{p}<0.05)$.

Table 3. Classes of lipids in whole and minced ray muscle ( $\mathrm{mg} / \mathrm{g}$ dry weight)

\begin{tabular}{lllll}
\hline & \multicolumn{1}{l}{0 days } & \multicolumn{2}{l}{7 days } \\
\cline { 2 - 5 } & Whole & Minced & Whole & Minced \\
\hline Phospholipids & $7.43(0.94)^{\mathrm{a}}$ & $9.20(1.12)^{\mathrm{a}}$ & $7.30(1.25)^{\mathrm{a}}$ & $8.80(1.82)^{\mathrm{a}}$ \\
Sterol ester + waxes & $0.00(0.00)$ & $0.00(0.00)$ & $0.00(0.00)$ & $0.00(0.00)$ \\
Triacylglycerides & $0.00(0.00)$ & $0.00(0.00)$ & $0.00(0.00)$ & $0.00(0.00)$ \\
Free fatty acids & $0.94(0.03)^{\mathrm{a}}$ & $1.19(0.20)^{\mathrm{a}}$ & $2.73(0.49)^{\mathrm{b}}$ & $3.04(0.47)^{\mathrm{b}}$ \\
Sterols & $1.79(0.09)^{\mathrm{a}}$ & $2.48(0.43)^{\mathrm{a}}$ & $1.72(0.17)^{\mathrm{a}}$ & $1.98(0.35)^{\mathrm{a}}$ \\
\hline
\end{tabular}

Standard deviations in parentheses, $\mathrm{n}=2$.

The sample was minced when it arrived in the laboratory (day 0) and after the wings had been kept in ice storage for seven days.

Means within the same rows with different superscript letters are significantly different $(\mathrm{p}<0.05)$. 